\title{
Statistical study on bodyweight and body fat among students from the Physical Education and Sport Faculty in Iași
}

\author{
Marius NECULĂEŞ ${ }^{1}$, Paul LUCACI ${ }^{2}$
}

\begin{abstract}
This papers aims at identifying the mean body mass index and body fat percentage among students from Physical Education and Sport Faculty in Iaşi.

The study was conducted on a series of 297 students majoring in Physical Education and Sports, but also in Kinetotherapy and Special Motricity (bachelor studies and master studies). By determining the body mass index mean and body fat mean for students within five specialties, we managed to classify them into categories. The assessment of body mass index was conducted using the standard formula BMI= weight in kilograms/height in meters ${ }^{2}$ and that of body fat using the Fat Track II body fat calliper.

Research findings highlighted that the body mass index mean values for each academic year range within normal parameters. As for body fat, the mean value of all academic years ranges in the "very good" and "good" categories. Whereas most mean values range within normal limits, it must not be neglected that overweight or underweight cases were also pinpointed, which should be a warning sign for the future specialists in the field of Physical Education and Sports.
\end{abstract}

Key words: body fat, body mass index, body fat calliper, overweight.

\section{Rezumat}

Lucrarea de faţă îţi propune să identifice media indicelui de masă corporală şi a procentului de grăsime a studenţilor de la Facultatea de Educaţie Fizică şi Sport din Iaşi.

Studiul a fost realizat pe un lot de 297 de studenţi din cadrul specializărilor de Educaţie Fizică și Sport și Kinetoterapie şi Motricitate Specială, de la programele de licenţă şi de masterat. Prin procesul de determinare a mediei indicelui de masă corporală şi a procentului de grasime a studenţilor de la cele cinci specializări, am realizat încadrarea în categoriile specifice. Evaluarea indicelui de masă corporală a fost realizat prin intermediul formulei standard $\mathrm{IMC}=\mathrm{g} / \mathrm{h}^{2}$ şi a procentului de grăsime cu ajutorul pliometrului FatTrackII.

Rezultatele cercetării au evidențiat faptul că în ceea ce privește valorile medii ale indicelui de masă corporală a fiecărui an de studiu nu există valori care să depășească pragul normalității. Dacă ne raportăm la procentul de grăsime, valoarea medie a tuturor anilor de studiu se încadrează în categoria "foarte bine" şi respectiv "bine". Chiar dacă majoritatea valorilor medii se încadrează în limitele normale, nu trebuie neglijat faptul că există și cazuri de supraponderalitate ori de subponderalitate, care ar trebui să devină un semn de întrebare pentru viitorii specialişti în domeniul Educaţiei Fizice şi Sportului.

Cuvinte cheie:procent grăsime, indice masă corporală, pliometru, supraponderali

\footnotetext{
1Lecturer PhD, ”Alexandru Ioan Cuza” University, Iaşi, Romania, Faculty of Physical Education and Sport, e-mail: neculaes_marius@yahoo.com ${ }^{2}$ Physical therapist, Lucaci Paul
} 


\section{Introduction}

Weight represents the sum of variable elements, some of which fixed (weight of the skeleton, of the nervous system, of the skin and of the organs) and some of which highly variable (muscles, fat and infiltration water within the tissues) [3].

Overweight represents a lack of balance between caloric input and energy consumption, and it leads to increased bodyweight by $10 \%$ to $20 \%$ compared to normal weight.

Certain signs are actually visible, though sometimes overweight may install rather insidiously. Continuous and rather fast weight loss may follow certain diseases characterized by loss of appetite, while weight gain that may trigger obesity is usually a long-term accumulation process (several years or decades). Both processes - excessive weight gain or weight loss - represent significant risk factors for health, reason for which weekly self-weighing and noting the results is a normal attitude for those who wish to have a healthy and happy life.

The amount and proportions of body fat has remained a central element in the analysis of body composition, due to the negative perception of the correlation between fat and health, sports and sports performance [4].

In order to have a correct view on normal weight, the best solution is to calculate the Body Mass Index (BMI), which is the most useful and practical indicator for overweight and obesity [1].

It is worth stating that BMI calculation must consider individual particularities: age, gender, lean mass, sports activity, workplace, etc.

In addition, there are several obesity classification scales, some of the best known being the American Society for Bariatric Surgery standards or World Health Organization standards. According to the first, obesity by BMI is classified as follows:

- Underweight - a weight lower than the ideal weight and a body mass index lower than 18.5 $\mathrm{kg} / \mathrm{m}^{2}$;

- Normal - BMI between 18.5 and $24.9 \mathrm{~kg} / \mathrm{m}^{2}$;

- Overweight - BMI ranging between 25 and 29.9

$\mathrm{kg} / \mathrm{m}^{2}$;

- Class I obesity - BMI ranging between 30 and 34.9 $\mathrm{kg} / \mathrm{m}^{2}$;

- Class II obesity - BMI between 35 and $39.9 \mathrm{~kg} / \mathrm{m}^{2}$;

- Class III obesity (morbid obesity) - BMI exceeding $40 \mathrm{~kg} / \mathrm{m}^{2}$.
Body fat percentage is a much more useful and reliable indicator for health status. Naturally, there are very thin persons who are ill, too, but diseases specific to the modern man are mainly correlated with body fat levels, because it reflects an unhealthy lifestyle, characterized by great amounts of bad food, less exercise, and high levels of stress.

In certain families, there is a genetic predisposition for weight gain, but this aspect is often hard to prove, because a family may have the same lifestyle and similar eating habits, which determine a predisposition to obesity for the entire family. [5] According to the instructions of the fat-o-meter used, the values of reference are represented in the table below:

Table I. Reference values for body fat index

\begin{tabular}{lccccc}
\hline & Excellent & $\begin{array}{c}\text { Very } \\
\text { good }\end{array}$ & Good & Bad & $\begin{array}{c}\text { Very } \\
\text { bad }\end{array}$ \\
\hline Males & $<11$ & 11.1 & 15.1 & 19.1 & $>23$ \\
& & $\sim 15$ & $\sim 19$ & $\sim 23$ & \\
\hline Females & $<19$ & 19.1 & 22.1 & 25.1 & $>30$ \\
& & $\sim 22$ & $\sim 25$ & $\sim 30$ & \\
\hline
\end{tabular}

Measuring the skin folds is necessary for assessing body composition, because they include a double layer: of the skin and of the subcutaneous fat tissue. [2]

\section{Materials and methods}

The study was conducted on a series of 297 subjects aged between 19 and 24, of whom 127 were females and 167 were males, students from the Iași Physical Education and Sport Faculty.

We assessed body mass index using the standard formula BMI= weight in kilograms/height in meters ${ }^{2}$ and body fat using the Fat Track II body fat calliper. There were three cutaneous folds measured according to the requirements of the fat-o-meter used: for male subjects, we assessed the pectoris major fold, the abdominal fold, and the hip fold; for female subjects we assessed the triceps fold, abdominal fold, and hip fold. We analysed the pectoris major fold on its oblique trajectory, formed along its margin, halfway between the anterior axillary line and the nipple. The triceps fold was vertical on the posterior side of the arm, halfway between the acromion and the radius, with the arm in supination. The abdominal fold used was horizontal, formed $3 \mathrm{~cm}$ laterally and $1 \mathrm{~cm}$ below the navel; the hip fold was vertical and we 
measured it on the median line of the anterior hip side, halfway between the inguinal fold and the upper margin of the kneecap.

All these measurements were conducted on the right side of the body and repeated three times on the same spot.

\section{Results}

To highlight the results, we interpreted graphically the values obtained on this series of subjects. We calculated the arithmetic mean values ofthebody mass index and of values obtained after measurements conducted using the fat-o-meter, in order to compare the data obtained for each academic year with the values of reference.

Hence, in Figure 1, we illustrated the mean values of body mass index and body fat for students within the five specialties of the Physical Education and Sport Faculty.

Figure 1, shows that the mean values of body mass index for each specialty range within normal limits for females. The same things apply for males, except for master students at the specialty of Kinesiotherapy in Sports Traumatology (second year), who scored the mean value of $25.069 \mathrm{~kg} / \mathrm{m}^{2}$, categorized as overweight.

\begin{tabular}{|c|c|c|c|c|}
\hline \multirow{2}{*}{ Academic year } & \multicolumn{2}{|c|}{ Female sex } & \multicolumn{2}{c|}{ Male sex } \\
\cline { 2 - 5 } & BMI $\left(\mathrm{wk} / \mathrm{h}^{2}\right)$ & Body fat & BMI $\left(\mathrm{wk}^{\mathrm{k}} / \mathrm{h}^{2}\right)$ & Body fat \\
\hline EFS II & 20.55 & 21.95 & 23.69 & 11.43 \\
\hline EFS III & 20.85 & 21.008 & 23.78 & 12.35 \\
\hline KMS II & 20.65 & 21.41 & 22.45 & 13.01 \\
\hline KMS III & 21.13 & 19.56 & 23.28 & 11.13 \\
\hline FECI & 21.17 & 19.36 & 24.22 & 13.57 \\
\hline FEC II & 20.30 & 19.22 & 24.55 & 14.1 \\
\hline ASTLE I & 24.6 & 19.6 & 24.66 & 11.74 \\
\hline ASTLSE II & 22.83 & 21.8 & 24.85 & 14.36 \\
\hline KTS I & 21.16 & 21.13 & 23.26 & 11.004 \\
\hline KTS II & 21.23 & 19.12 & 25.06 & 16.93 \\
\hline
\end{tabular}

Figure 1. Body mass index and body fat for the students within the five specialities Legend: $\mathrm{EFS}=$ Physical Education and Sport; $\mathrm{KMS}=$ Physicaltherapy and Special Motricity; FEC = Fitness and Body Aesthetics; ASTLSE = Pasttime Activities and Extreme Sports

As for the body fat of females within the study series, the mean value of all specialties corresponds to the "very good" category $\left(19.1 \sim 229 \mathrm{~kg} / \mathrm{m}^{2}\right)$; the same conclusion was drawn for males, but only in four specialties, because the master students of Kinesiotherapy in Sports Traumatology (second year) scored "good" (15.1 $\left.19 \mathrm{~kg} / \mathrm{m}^{2}\right)$ - the mean value of $16.93 \mathrm{~kg} / \mathrm{m}^{2}$.
In Figure 2, we interpreted comparatively the mean values of body mass index in the females of the five specialties:

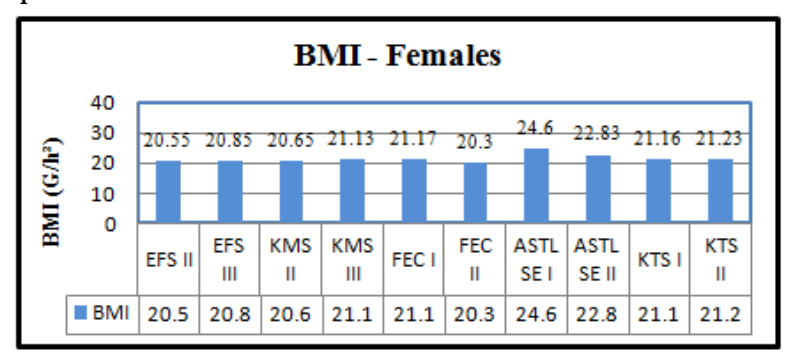

Figure 2. Mean of body mass index - females

Figure 2, illustrates that the females of the five specialties have a body mass index mean that corresponds to normal parameters.

In Figure 3, we interpreted comparatively the body fat of females of the five specialties:

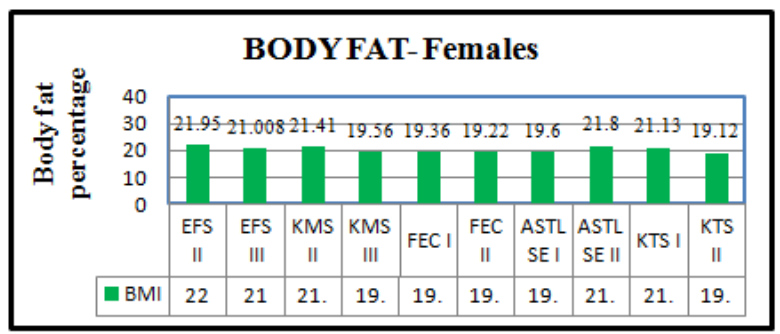

Figure 3. Body fat mean - females

Figure 3, demonstrates that the mean value of body fat for females corresponds to the "very good" category: between $19.1 \sim 22 \mathrm{~kg} / \mathrm{m}^{2}$.

In Figure 4, we interpreted comparatively the body mass index for the males of the five specialties:

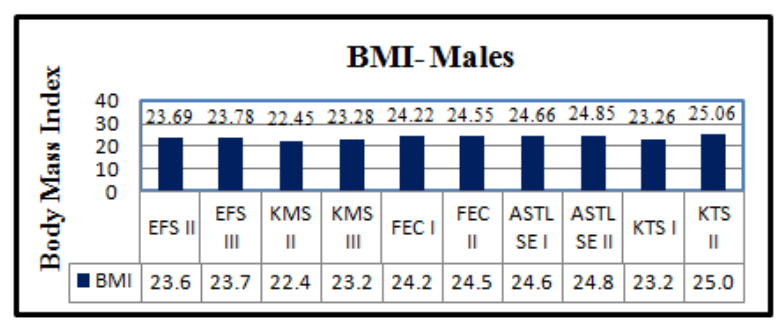

Figure 4, Body mass index mean for males

Figure 4, indicates that the mean value of body mass index for the four specialties corresponds to normal weight, while the master students at the specialty of Kinesiotherapy in Sports Traumatology are overweight: their mean body mass index is 25.06 $\mathrm{kg} / \mathrm{m}^{2}$. 
Figure 5, features the comparative interpretation of body fat for the males of the five specialities:

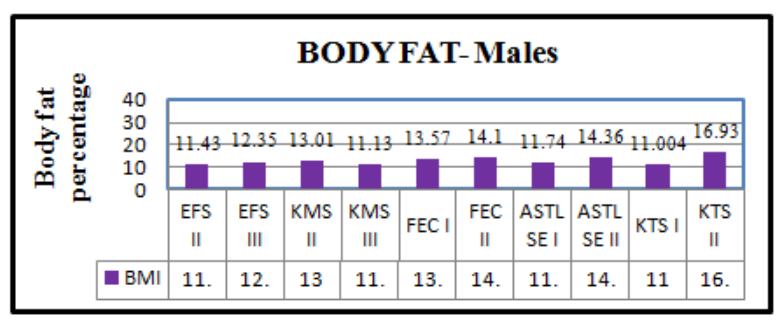

Figure 5 , Mean of body fat for males

As illustrated in Figure 5, body fat in males corresponds to the "very good" category for four specialties, while the master students at the specialty of Kinesiotherapy in Sports Traumatology (second year) scored "good" - mean body fat of $16.93 \mathrm{~kg} / \mathrm{m}^{2}$.

In Figure 6, we illustrated graphically the 127 females and their body mass index at the moment of the evaluation.

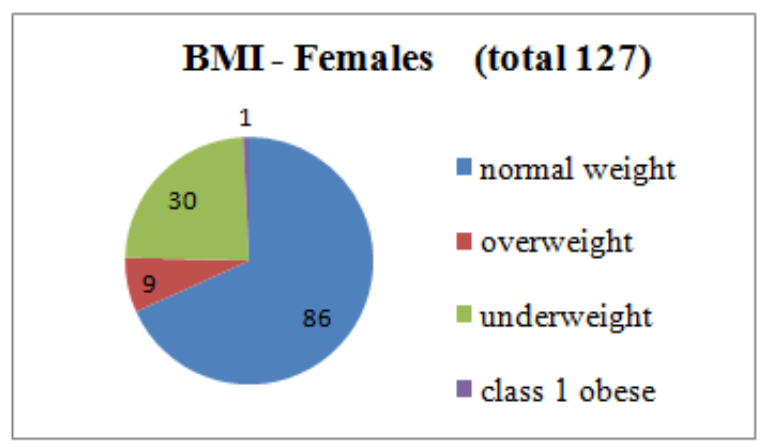

Figure 6. Number of females in each body mass index category

As shown in Figure 6, upon the evaluation, of the 127 females within our study series, 86 had normal weight, 9 were overweight, 30 were underweight and only one female was Class 1 obese.

Figure 7, illustrates the body mass index of the 167 male subjects and their distribution into various categories. From the 167 males assessed, 123 had normal weight, 33 were overweight, 7 were underweight, while 4 were Class 1 obese.

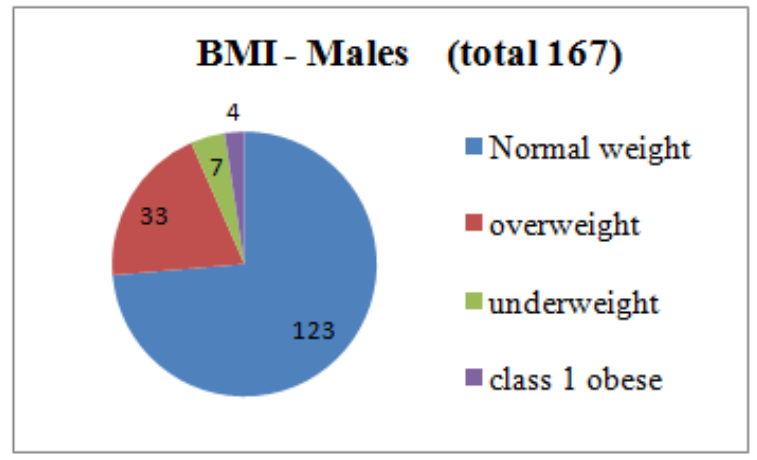

Figure 7, Number of males in each body mass index category

Figure 8, shows the body fat of the 127 females and their distribution within each specific category:

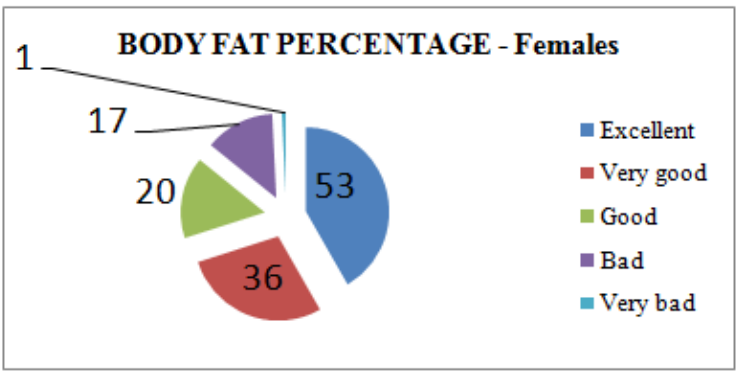

Figure 8, Number of females within each body fat percentage category

Figure 8, clearly shows that, at the evaluation, 53 females scored "excellent" for body fat percentage, 36 "very good", 20 "good", 17 "bad" and 1 "very bad".

Figure 9, features the body fat representation of the 167 males, with their classification into specific categories:

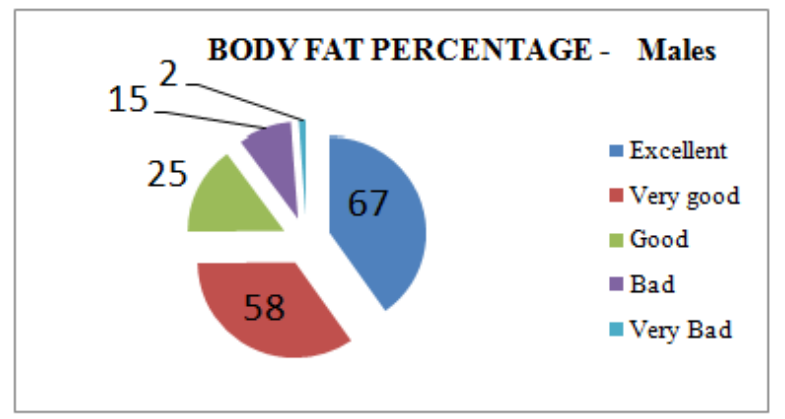

Figure 9 Number of males within each body fat percentage category

As featured in Figure 9, at the evaluation, 67 males scored "excellent" for body fat percentage, 58 "very good", 25 "good", 15 "bad" and 2 "very bad".

\section{Discussions}

According to the Nutrition and Food Sciences journal, obesity represents one of the most 
important cause of annually global death and they estimate that it will increase exponentially by 2025 . An article named Physical Activities as Obesity Prevention Tools, published in Journal of Women's Health Care, highlights two primary causes for the increase in world obesity: lack of an active lifestyle and poor nutritional habits. We can't connect this two causes of obesity with our results but we can raise a question mark for the nutritional specialists and also for our students.

\section{Conclusions}

The findings of our statistical study show that, in the case of mean values obtained for the five specialties, no significant difference was found between normal values and our values for body mass index and for body fat percentage. However, when we compared the situation considering individual values and the graphs by categories, it became obvious that a significant number of students did not range within normal limits, for both body mass index and body fat percentage, which should be a warning sign for those persons and for others.

\section{References}

1. Drăgan I. (2002).Medicină Sportivă, Ed. Medicală, Bucharest, pag. 220.

2. Easton R, Reilly T.(2009). Kinanthropometry and Exercise Physiology Laboratory Manual, Tests, Procedures and Data, 3rd edition, vol. I, Routledge Tazlor and Francis Group, London and New York, pag. 23.

3. Bjorntorp P. (2001).International Textbook of Obesity, Ed. John Wiley \& Sons Ltd, Göteborg, pag. 3.

4. Gingină C. et al., 2006, Obezitatea, Ed. Medicală Antaeus, Bucharest, pag. 8.

5. Cordun M.(2009).Kinantropometrie, Ed. Cd Press, Bucharest, pag. 41.

6. Soldati L, Tomei S , Wang E, Kerkadi A, ElObeid T, Amuna P , Chouchane L and Terranegra A (2016), Potential Nutrigenomic Approaches to Reduce the High Incidence of Obesity in Qatar, Sodlati et al., J Nutr Food Sci, 6:2, pg 1.

7. Vaclav B. (2016)Physical Activities as Obesity Prevention Tools, Bunc, J Women's Health Care, 5:2, pag. 1. 